\title{
Investigating the construct validity of quality measures influencing online shopping in a South African context
}

\author{
Yu-ting HUNG-JOUBERT \\ University of South Africa, Pretoria, South Africa \\ hungy@unisa.ac.za
}

\begin{abstract}
Online shopping has become popular over the years and is a widely used way to purchase goods and services. For online retailers to succeed, it is important that they have a quality website to attract and retain customers. The aim of this study was to investigate the construct validity of three respective measurement instruments related to website quality factors, namely; system, information and service quality factors, which may influence consumers within the online shopping environment in a South African context. Primary data was collected through selfadministered questionnaires. The demographic and online shopping profile of the sample are presented and followed by confirmatory and exploratory factors analyses on the three instruments. The confirmatory factor analysis found poor fit for the original hypothesised models for each of the scales; further exploratory factor analyses revealed slightly different dimensionalities underlying the scales, yet these were still somewhat aligned with the theoretical framework from which the original scales were derived. Despite this, the study provides a platform for future revision of the scales and future research into website quality factors within the online shopping environment in a South African context.
\end{abstract}

Keywords: online shopping, website quality, system quality, information quality, service quality, South Africa

Please cite the article as follows: Hung-Joubert, Y, (2017), "Investigating the construct validity of quality measures influencing online shopping in a South Africa context", Marketing \& Management. Challenges for the Knowledge Society, Vol. 12, No. 3, pp. 376-401. DOI: 10.1515/mmcks-2017-0023.

\section{Introduction}

E-commerce has grown significantly over the years and has become an essential part of a consumers' life (Cebi, 2013), as well as an important channel for businesses (Chiu, Wang, et al., 2012). Online shopping, the most popular aspect of e-commerce, has become increasingly common (Sam and Tahir, 2009; Hsieh and Tsao, 2014). Even though the South African online shopping market is still relatively small compared global markets, accounting for $1.2 \%$ of South Africa retail sales, it is still rising (Prinsloo, 2016). Due to the fact that consumers have an abundance of shopping websites to shop from, attention is now being focused on the quality of the website (Shin, et al., 2013). A quality website ensures better online experiences, which is important for consumers and is crucial for online retailers as it attracts and retains customers (Hasanov and Khalid, 2012). According to Bilgihan and Bujisic (2014) online shopping is unique in the sense that users base their judgement on what is presented on the website. Therefore, online retailers are becoming increasingly mindful of the quality of their websites (AlManasra et al., 2013).

In attempting to determine the quality of websites, a number of authors have adapted and used information system research as a basis (Loiacono et al., 2002; Barnes and Vidgen, 2002; Webb and Webb, 2004). Al-Debei et al. (2014:710) state that a shopping website using web technologies to manage its processes can be referred to as an information system. Xu et al. (2013) state that from consumers' perspectives, it is 
common to assess a website on its system, information and service aspects. This research therefore used the system, information and service quality factors identified by Delone and McLean's information system success model (2003) as the basis for this research to determine the factors that influence online shopping in the South African context. Various authors have highlighted the importance of system, information and service quality factors, which have a direct and indirect impact on users' satisfaction and their intention to use a website within the e-commerce and online shopping context (Brown and Jayakody, 2008; Wang, 2008; Chen and Cheng, 2009; Ziaullah et al., 2015).

\section{Literature review}

\section{System quality}

Hsu et al. (2014) simply describe system quality as the desired technical characteristics of a website. System quality, therefore, measures users' perceived user friendliness of a shopping website (Hsu et al., 2012). Even though the information presented on the website is crucial, it is the system that ensures that the information is delivered efficiently and effectively (Hwang et al., 2012). According to DeLone and McLean (2003) system quality factors include usability, reliability, availability, adaptability and response time. Usability refers to the layout and functionality of a website (Kühn et al., 2015). Usability, in essence, is how easy the website is for users to use, understand, operate, find and navigate (Hasan and Abuelrub, 2011). Availability refers to the system being available to perform when needed and to operate correctly. Availability, essentially, refers to users being able to access or make use of a website at any given time. Reliability refers to the system performing how it should for a specified time and the extent to which users can trust the system (Alrawashdeh et al., 2013; Al-Mamary, et al., 2013). Reliability of a shopping website therefore ensures that it performs as intended to allow for easy online shopping, while ensuring the authenticity of products and services (Hanai and Oguchi, 2009). Adaptability refers to a system being able to modify itself efficiently to changes (Andersen and Gronau, 2007; Nechkoska, 2015). Adaptability therefore ensures that a website is able to adapt the users' requirements. Response time refers to the amount of time it takes for a website to perform a function or respond to a request (Gao, 2013). Response time therefore ensures how slow or fast the website takes to perform a function a user has requested.

\section{Information quality}

Information quality refers to the content of an online system which should be personalised, complete, relevant, easy to understand and secure (DeLone and McLean, 2003; Hsu et al., 2014). Content has one of the most significant influences on the users' perceptions of a website (Coker, 2013) as well as their potential buying behaviours (Jeon, 2009). Content on a shopping website includes detailed information on the products and services offered, the order status, corporate policies or public relations, and by providing these, users have a better idea of what to expect, and this decreases uncertainty and risk associated with online shopping (Thongpapanl and Ashraf, 2011). Personalisation refers to a website providing content that is tailored for every user (Jackson, 2007). A shopping website should have recommendation mechanisms in place that provides specific content for a particular user based on their preferences and interests (Liang et al., 2007; Sharma et al., 2013). Completeness can be seen as the extent to which the content is available and sufficient enough to complete a particular task (Kandari, 2010). Relevancy, on the other hand, is the extent in which content is 
relevant, appropriate and useful for a particular task (Kandari, 2010; Samsi et al., 2016). The content on a shopping website should therefore be complete and relevant to assist users when shopping online. Ease of understanding refers to the extent which information is clear with ambiguity and easy to understand (Knight and Burn, 2005; Huang and Benyoucef, 2013). Secureness is the security of payments and ensuring the privacy of any information that is shared by the users (Afshardost et al., 2013). An important risk that organisations need to address is the safety and security of transactions (Alharbi et al., 2013). Online shoppers will not make use of a shopping website and provide their personal and financial information if it is not secure (Yu and Zhao, 2013).

\section{Service quality}

Service quality describes the support a website provides for its users (Hamid, 2008). Service quality measures the users' judgement on the quality of the service provided by an online retailer (Hsu et al., 2012). Service quality factors include responsiveness, assurance, empathy, reliability and follow-up services (Delone and Mclean, 2003; Zeithaml et al., 2002). Responsiveness is thus the user's perception of a website's employees providing helpful and responsive assistance (Qutaishat, 2012). Responsiveness, in essence, is the employees' willingness to provide timely services (Parasuraman et al., 1988 in Ramseook-Munhurrun, 2012). Assurance is the extent in which a website and its employees are able to convey trust and confidence by being knowledgeable and courteous towards users, as well as having a good reputation, establish relationships with well-known businesses and use third party seals for privacy and security (Saha and Grover, 2011; Swaid and Wigand, 2009). Empathy is the amount of attention given to online shoppers, as well as the extent in which employees are caring towards online shoppers (Daniel and Berinyuy, 2010; Yu and Zhao, 2013). Empathy in essence reflect the employees' genuine intention towards the customers' and giving them individualised attention (Ramseook-Munhurrun, 2012). Reliability is the timely, dependable and consistent performance of services (Loke et al., 2011; Parasuraman et al., 1985 in Yarimoglu, 2014). Reliability mainly determines if employees provide accurate services the first time and keep to their promises (Grönroos, 1983 in Kabir and Carlsson, 2010). Follow-up services are crucial as it encourages customers to return to the site and also encourages them to provide reviews, which offers valuable feedback for the online retailer to determine whether they are satisfied with the product and if they have any recommendations for improvement in terms of service delivery (Levin, 2013).

\section{Research methodology \\ Aim}

The aim of the study was to investigate the construct validity of three respective measurement instruments related to website quality factors, namely; system quality factors, information quality factors and service quality factors, within the online shopping environment which may influence consumers in a South African context.

\section{Procedure and design}

A quantitative approach was adopted for the study with data being collected using an internet-based self-administered questionnaire where a link was posted via social media platforms and online forums which was completed by respondents. The 
questionnaire contained the System Quality Factors scale, the Information Quality Factors scale and the Service Quality Factors scale based on the literature review. Nonprobability, convenience sampling was used in the collection of the data.

\section{Measurement instruments}

For all three scales, respondents were required to indicate their agreement with statements related to the various quality factors on a 5-point Likert scale ranging from 1 - 'strongly disagree' to 5 - 'strongly agree'.

The System Quality Factors scale is a 23-item scale which measures the influence of five system quality factors affecting South African consumers when shopping online. The system quality factors measured include: Usability, Availability, Reliability, Adaptability, and Response Time.

The Information Quality Factors scale is a 23-item scale which measures the influence of five information quality factors influencing South African consumers when shopping online. The information quality factors measured include: Personalisation, Completeness, Relevancy, Ease of Understanding, and Secureness.

The Service Quality Factors scale is a 26-item scale which measures five service quality factors. These factors include Responsiveness, Assurance, Empathy, Reliability, and Follow-up Service, which may influence South African consumers when shopping online.

\section{Sample}

Table 1 provides a detailed breakdown of the sample. The overall sample for the study consisted of 123 respondents with $32.5 \%(n=40)$ males and $67.5 \%(n=83)$ females. In terms of age the majority of the sample were between the ages of $26-35(57.7 \%, n=71)$ and $18-25(26.8 \%, n=33)$. The sample stems predominantly from Gauteng $(82.9 \%$, $\mathrm{n}=102$ ) with marginal representation from other provinces. With regards to the employment status, the majority of respondents indicated that they were permanently employed $(70.7 \%, \mathrm{n}=87)$. Furthermore, the majority of the sample had higher qualifications ranging from a diploma/advanced certificate to a Doctoral degree.

Table 1. Demographic breakdown of sample

\begin{tabular}{|c|c|c|}
\hline & $\begin{array}{l}\text { Number of } \\
\text { respondents (n) }\end{array}$ & Percentage \\
\hline \multicolumn{3}{|l|}{ Gender } \\
\hline Male & 40 & 32.5 \\
\hline Female & 83 & 67.5 \\
\hline \multicolumn{3}{|l|}{ Age } \\
\hline $18-25$ years old & 33 & 26.8 \\
\hline $26-35$ year old & 71 & 57.7 \\
\hline $36-45$ years old & 9 & 7.3 \\
\hline $46-65$ years old & 10 & 8.1 \\
\hline \multicolumn{3}{|l|}{ Province } \\
\hline Gauteng & 102 & 82.9 \\
\hline Western Cape & 14 & 11.4 \\
\hline KwaZulu-Natal & 3 & 2.4 \\
\hline Mpumalanga & 2 & 1.6 \\
\hline North West & 1 & 0.8 \\
\hline \multicolumn{3}{|l|}{ Employment status } \\
\hline Permanently employed & 87 & 70.7 \\
\hline Self-employed & 19 & 15.4 \\
\hline
\end{tabular}




\begin{tabular}{|l|l|l|}
\hline Unemployed - looking for work & 6 & 4.9 \\
\hline Part-time employed & 4 & 3.3 \\
\hline Unemployed - not looking for work & 1 & 0.8 \\
\hline Other & 6 & 4.9 \\
\hline Highest qualification & \multicolumn{2}{|l|}{} \\
\hline Matric & 12 & 9.8 \\
\hline Higher Certificate & 1 & 0.8 \\
\hline Diploma or Advanced Certificate & 15 & 12.2 \\
\hline Bachelor's Degree & 32 & 26.0 \\
\hline Post-grad Diploma & 2 & 1.6 \\
\hline Honour's Degree & 40 & 32.5 \\
\hline Master's Degree & 19 & 15.4 \\
\hline Doctoral Degree & 1 & 0.8 \\
\hline Other & 1 & 0.8 \\
\hline
\end{tabular}

Source: Author's own research results.

Table 2 below provides a robust indication of the online shopping profile of respondents. The majority of respondents $(85.4 \%, \mathrm{n}=105)$ access the internet a few times almost every hour with $75.5 \%(n=93)$ of respondents shopping online at least once per month.

Table 2. Online shopping profile

\begin{tabular}{|l|l|l|}
\hline & $\begin{array}{l}\text { Number of } \\
\text { respondents (n) }\end{array}$ & Percentage \\
\hline Online access frequency & 105 & 85.4 \\
\hline Online a few times per hour every day hour & 18 & 14.6 \\
\hline Online at least once per day & \multicolumn{2}{|l|}{} \\
\hline Online shopping frequency & 11 & 8.9 \\
\hline Shop at least once per day & 26 & 21.1 \\
\hline Shop at least once per week & 56 & 45.5 \\
\hline Shop at least once per month & 11 & 8.9 \\
\hline Shop at least once per year & 19 & 15.4 \\
\hline Missing &
\end{tabular}

Source: Author's own research results.

\section{Data analysis}

The data for the study was analysed using the Statistical Package for the Social Sciences version 20 (SPSS 20) in combination with AMOS 22. The data analyses process consisted of two stages. The first stage focused on examining the construct validity by conducting confirmatory factor analyses on the three instruments. Following this, the second stage of analyses adopted an exploratory approach with exploratory factor analyses also being conducted on the three instruments following the results of the initial confirmatory factor analyses.

\section{Confirmatory Factor Analyses}

Confirmatory factor analyses using structural equation modelling (SEM) with maximum likelihood estimation was conducted on all three instruments to examine the underlying factor structure and dimensionality of the instruments. In terms of goodness-of-fit indicators for the models the following measures were used to determine the overall fit of the models (Hair, Black, Babin \& Anderson, 2010; Hu \& Bentler, 1995, 1998, 1999): 
i) The chi-square test statistic - significant chi-square $(\mathrm{p}<.05)$ indicates bad fit

ii) Goodness of Fit Index (GFI) - values $\geq .95$ indicate good fit

iii) Comparative Fit Index (CFI) - values $\geq .95$ indicate good fit

iv) Root mean square error of approximation (RMSEA) - values $<.06$ indicate good fit yet values below .08 may also indicate acceptable fit.

Factors within the confirmatory models were allowed to correlate and modification indices (significantly correlated errors) were used to ensure the best fit for the models with significant errors being allowed to correlate based on their theoretical alignment, their content and the judgment of the researcher.

\section{Exploratory Factor Analyses}

In order to further explore the underlying factor structure of the three instruments following the results of the initial confirmatory factor analyses, common factor analyses using the principal axis factoring method (with an oblique (Direct Oblimin) rotation) as well as reliability analyses were conducted on the data. Factors were consequently extracted using a combination of methods including the Kaiser-criterion or latent root criterion (eigenvalues-greater-than-one) and scree-plot test. The number of factors extracted was also considered in light of the a priori criterion based on the theoretical framework posited for the factors underlying the instruments. In line with the general rule of thumb and in consideration of the sample size, only items with a factor loading of $\geq .4$ were considered in the analyses (Field, 2005; Hair et al., 2010). With regard to the reliability analyses, Cronbach's alpha coefficients were calculated for each of the factors/subscales.

\section{Findings and results}

In the interest of clarity, the results of both the confirmatory and exploratory factor analyses for each of the instruments will be presented. The results for the System Quality Factors scale will be presented first, followed by the Information Quality Factors scale, and the Service Quality Factors scale will finally be shown.

\section{System quality factors scale}

Confirmatory factor analysis - System Quality Factors scale

In line with the underlying theoretical framework, a five-factor model was used in the confirmatory factor analysis of the System Quality Factors scale with all items loading highly on the various factors and all factor loadings being significant $(p<.001)$ (see table 3).

Table 3. System Quality Factors scale confirmatory factor analysis standardised item factor loadings $(n=123)$

\begin{tabular}{|l|l|l|l|l|l|l|}
\hline Item & Scale & Usability & Availability & Reliability & Adaptability & $\begin{array}{l}\text { Response } \\
\text { Time }\end{array}$ \\
\hline $\mathbf{1}$ & Usability & .801 & & & & \\
$\mathbf{2}$ & Usability & .783 & & & & \\
$\mathbf{3}$ & Usability & .787 & & & & \\
$\mathbf{4}$ & Usability & .811 & & & \\
$\mathbf{5}$ & Usability & .729 & & & \\
$\mathbf{6}$ & Usability & .780 & & & & \\
\hline $\mathbf{7}$ & Availability & & .629 & & & \\
$\mathbf{8}$ & Availability & & .687 & & &
\end{tabular}




\begin{tabular}{|l|l|l|l|l|l|l|}
\hline Item & Scale & Usability & Availability & Reliability & Adaptability & $\begin{array}{l}\text { Response } \\
\text { Time }\end{array}$ \\
\hline $\mathbf{9}$ & Availability & & .728 & & & \\
\hline $\mathbf{1 0}$ & Reliability & & & .843 & & \\
$\mathbf{1 1}$ & Reliability & & .740 & & \\
$\mathbf{1 2}$ & Reliability & & .619 & & \\
$\mathbf{1 3}$ & Reliability & & .616 & & \\
\hline $\mathbf{1 4}$ & Adaptability & & & .524 & \\
$\mathbf{1 5}$ & Adaptability & & & .725 & \\
$\mathbf{1 6}$ & Adaptability & & & .899 & \\
$\mathbf{1 7}$ & Adaptability & & & & .837 & .789 \\
\hline $\mathbf{1 8}$ & Response & & & & .818 \\
$\mathbf{1 9}$ & Time & Response & & & & .860 \\
$\mathbf{2 0}$ & Time & Response & & & & .850 \\
$\mathbf{2 1}$ & Time & Response & & & & \\
$\mathbf{2 2}$ & Time & Response & & & & .813 \\
$\mathbf{2 3}$ & Time & Response & & & & .744 \\
\hline
\end{tabular}

In terms of the model goodness of fit, the overall chi-square test was found to be significant with $x^{2}(214)=399.657, \mathrm{p}<.001$, suggesting poor fit of the hypothesised model. Furthermore, the GFI $=.789(<.95), \mathrm{CFI}=.901(<.95)$ and the RMSEA $=.084(>$ .8) also indicated poor fit for the model (see table 4). Overall, the model thus did not fit the data in spite of the deceptively high factor loadings.

Table 4. System Quality Factors scale goodness-of-fit indices

\begin{tabular}{|l|l|l|l|l|l|l|}
\hline Model & $\boldsymbol{x}^{\mathbf{2}}$ & $\boldsymbol{d} \boldsymbol{f}$ & $\boldsymbol{p}$ & GFI & CFI & RMSEA \\
\hline Original model & 399.657 & 214 & $<.001$ & .789 & .901 & .084 \\
\hline
\end{tabular}

Strong relationships were evident among all the factors present in the model with moderate $(\geq .3)$ to strong $(\geq .5)$ and very strong $(\geq .7)$ positive correlations found between all the factors (see table 5).

Table 5. Factor correlation matrix for System Quality Factors scale

\begin{tabular}{|l|l|l|l|l|l|}
\hline Factor & Usability & Availability & Reliability & Adaptability & $\begin{array}{l}\text { Response } \\
\text { Time }\end{array}$ \\
\hline Usability & 1 & & & & \\
Availability & .675 & 1 & & & \\
Reliability & .719 & .687 & 1 & & \\
Adaptability & .452 & .741 & .468 & 1 & \\
Response Time & .557 & .691 & .697 & .698 & 1 \\
\hline
\end{tabular}

Source: Author's own research results.

Exploratory factor analysis - System Quality Factors scale 
Following the results of the confirmatory factor analysis, further exploratory factor analysis was conducted on the System Quality Factors scale to examine the underlying dimensionality.

Table 6. KMO and Bartlett's test of sphericity statistics for System Quality Factors scale

\begin{tabular}{|ll|l|}
\hline \multicolumn{1}{|l|}{ Kaiser-Meyer-Olkin measure of Sampling Adequacy } & .892 \\
\hline Bartlett's Test of Sphericity & Apprx. Chi-Square & 1981.646 \\
& df & 253 \\
Sig. & .000 \\
\hline
\end{tabular}

Source: Author's own research results.

The KMO measure (.892) and the Bartlett's test of sphericity x2 (253) $=1981.646$, $\mathrm{p}<.01$, suggested sufficient inter-correlation and common variance within the data to conduct an exploratory factor analysis (see table 6).

Examination of the Kaiser-criterion (eigenvalues-greater-than 1) as well as the scree-plot suggested that four factors be extracted (see figure 1). The a priori criterion, stipulating the extraction of five factors model based on the theoretical framework, produced unstable factors, items that cross-loaded onto more than one factor as well as factors which were difficult to interpret. Four factors were consequently extracted.

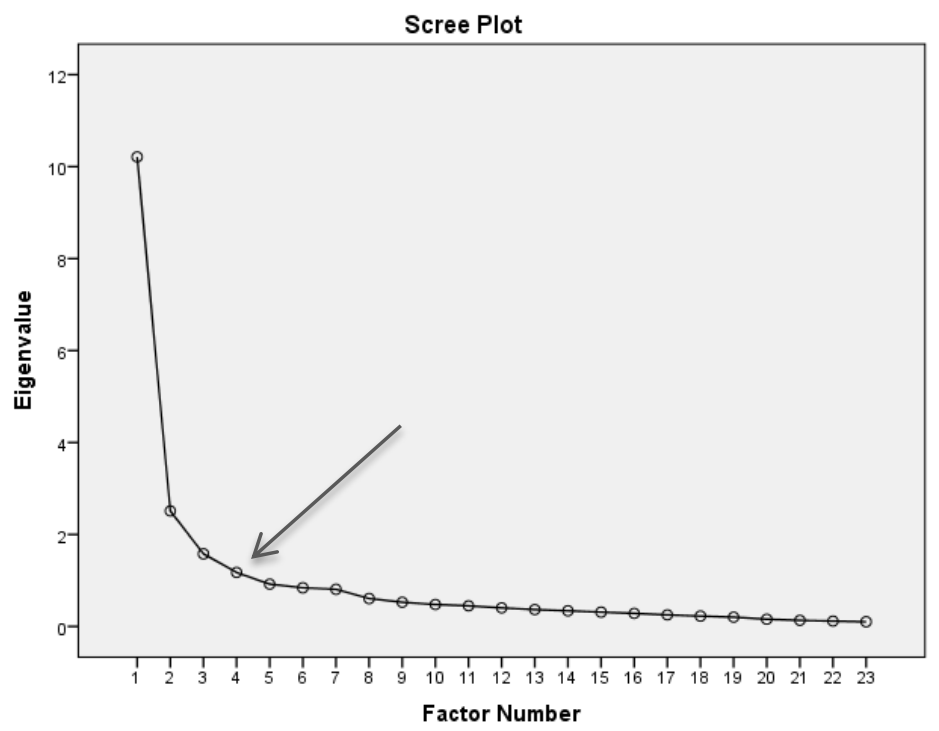

Figure 1. Scree-plot System Quality Factors scale

Source: Author's own research results.

The pattern matrix for the final factor solution after rotation is provided in table 7 below. Items 14, 11 and 5 did not load significantly $(<.4)$ on any of the factors (see table 7).

Table 7. Pattern matrix (rotated factor matrix) System Quality Factors scale

\begin{tabular}{|l|l|l|l|l|}
\hline \multirow{2}{*}{ Items } & \multicolumn{4}{|c|}{ Factor } \\
\cline { 2 - 5 } & $\mathbf{1}$ & $\mathbf{2}$ & $\mathbf{3}$ & $\mathbf{4}$ \\
\hline $\mathbf{2 2}$ & .874 & & & \\
$\mathbf{2 3}$ & .761 & & & \\
$\mathbf{1 9}$ & .732 & & & \\
$\mathbf{2 1}$ & .687 & & & \\
\hline
\end{tabular}




\begin{tabular}{|l|l|l|l|l|}
\hline \multirow{2}{*}{ Items } & \multicolumn{4}{|c|}{ Factor } \\
\hline & $\mathbf{1}$ & $\mathbf{2}$ & $\mathbf{3}$ & $\mathbf{4}$ \\
\hline $\mathbf{2 0}$ & .627 & & & \\
$\mathbf{1 8}$ & .551 & & & \\
$\mathbf{1 4}$ & & & & \\
$\mathbf{1 1}$ & & & & \\
$\mathbf{3}$ & & .886 & & \\
$\mathbf{1}$ & & .884 & & \\
$\mathbf{2}$ & & .850 & & \\
$\mathbf{4}$ & & .628 & & \\
$\mathbf{6}$ & & .507 & & \\
$\mathbf{5}$ & & & & \\
$\mathbf{1 3}$ & & & .744 & \\
$\mathbf{1 2}$ & & & .714 & \\
$\mathbf{1 0}$ & & & .429 & \\
$\mathbf{1 6}$ & & & & .818 \\
$\mathbf{1 7}$ & & & & .690 \\
$\mathbf{1 5}$ & & & & .616 \\
$\mathbf{8}$ & & & & .564 \\
$\mathbf{7}$ & & & & \\
$\mathbf{9}$ & & & & \\
\hline
\end{tabular}

Source: Author's own research results.

Table 8 provides a summary of the items which loaded significantly on the various factors.

Table 8. Significant items per factors extracted System Quality Factors scale

\begin{tabular}{|c|c|c|}
\hline & Factor 1 & \\
\hline Item & Content & Loading \\
\hline 18 & A shopping site that has a fast response time influences me to shop online. & .551 \\
\hline 19 & A shopping site that operates at good constant speeds influences me to shop online. & 732 \\
\hline 20 & A shopping site that has pages that load quickly influences me to shop online. & 627 \\
\hline 21 & A shopping site that has images that load quickly influences me to shop online. & 687 \\
\hline 22 & A shopping site that has links that open quickly influences me to shop online. & 874 \\
\hline \multirow[t]{2}{*}{23} & A shopping site that allows quick access to its services influences me to shop online. & .761 \\
\hline & Factor 2 & \\
\hline Item & Content & Loading \\
\hline 1 & A shopping site that is easy to use influences me to shop o & .884 \\
\hline 2 & A shopping site that is easy to navigate influences me to shop online. & 850 \\
\hline 3 & A shopping site that provides trouble-free shopping influences me to shop online. & 886 \\
\hline 4 & A shopping site that has a simple layout influences me to shop online. & 628 \\
\hline \multirow[t]{2}{*}{6} & A shopping site that is well organised influences me to shop online. & .507 \\
\hline & Factor 3 & \\
\hline Item & Content & Loading \\
\hline 10 & A shopping site that performs reliably influences me to shop online. & .429 \\
\hline 12 & $\begin{array}{l}\text { A shopping site that provides a safe shopping environment influences me to shop } \\
\text { online. }\end{array}$ & .714 \\
\hline \multirow[t]{3}{*}{13} & $\begin{array}{l}\text { A shopping site that ensures the authenticity of the products/services influences } \\
\text { me to shop online }\end{array}$ & .744 \\
\hline & Factor 4 & \\
\hline & Content & Loading \\
\hline 15 & $\begin{array}{l}\text { A shopping site that adapts to different screen device sizes influences me to shop } \\
\text { online. }\end{array}$ & .616 \\
\hline 16 & $\begin{array}{l}\text { A shopping site that adapts to different operating systems influences me to shop } \\
\text { online. }\end{array}$ & 818 \\
\hline 17 & $\begin{array}{l}\text { A shopping site that adapts to different user system specifications influences me to } \\
\text { shop online (e.g. portrait or landscape view). }\end{array}$ & .690 \\
\hline
\end{tabular}

Vol. 12, No. 3, Autumn, pp. 376-401, ISSN 1842-0206 | Management \& Marketing. Challenges for the Knowledge Society 
\begin{tabular}{l|l}
7 & A shopping site that is available 24/7 influences me to shop online.
\end{tabular}

A shopping site that avoids downtime due to maintenance influences me to shop online.

9 A shopping site that helps with error recovery influences me to shop online (e.g. when you need to refresh a page and your details are saved)

Source: Author's own research results.

Factor 1 was constituted mainly from items relating to the speed of online shopping sites with the item with the highest factor loading being 'A shopping site that has links that open quickly influences me to shop online'. The factor was thus labelled 'Response Time' (see table 8).

Items which loaded significantly onto factor 2 primarily focus on ease of use, simplicity and organisation. The highest loading items on the factor were 'A shopping site that provides trouble-free shopping influences me to shop online' and 'A shopping site that is easy to use influences me to shop online'. The factor was consequently labelled 'Usability' (see table 8).

Factor three contained items which focus on reliability, authenticity and the provision of a safe shopping environment. The item content thus seems to relate to the reliability and trustworthiness of the shopping site with the highest loading item being 'A shopping site that ensures the authenticity of the products/services influences me to shop online'. The factor was thus labelled 'Reliability' (see table 8).

The final factor, Factor 4, consisted of items which relate predominantly to the availability and adaptability of the shopping site. The highest loading item on the factor was 'A shopping site that adapts to different operating systems influences me to shop online'. The factor was thus labelled as 'Adaptability and Availability' (see table 8).

Similar to the findings from the confirmatory factor analysis, moderate positive correlations $(\geq .3)$ to strong positive correlations $(\geq .5)$ were found between all the extracted factors (see table 9).

Table 9. Factor correlation matrix for System Quality Factors scale (exploratory)

\begin{tabular}{|l|l|l|l|l|}
\hline & Factor 1 & Factor 2 & Factor 3 & Factor 4 \\
\hline Factor 1 & 1 & & & \\
Factor 2 & .360 & 1 & & \\
Factor 3 & .336 & .460 & 1 & \\
Factor 4 & .584 & .426 & .314 & 1 \\
\hline
\end{tabular}

Source: Author's own research results.

Table 10 below provides the Cronbach's Alpha reliability coefficients for each of the factors identified. All the factors/subscales showed good internal consistency and reliability with all the Cronbach's Alpha coefficients > 0.6 (Field, 2005; Hair, Black, Babin \& Anderson, 2010).

Table 10. Cronbach's alpha coefficients per factor System Quality Factors scale

\begin{tabular}{|l|l|l|}
\hline & Label & Cronbach's Alpha \\
\hline Factor 1 & Response Time & .922 \\
\hline Factor 2 & Usability & .902 \\
\hline Factor 3 & Reliability & .788 \\
\hline Factor 4 & Adaptability \& Availability & .845 \\
\hline
\end{tabular}




\section{Information Quality Factors scale}

Confirmatory factor analysis - Information Quality Factors scale

Confirmatory factor analysis of the Information Quality Factors scale was based on a five-factor model in line with the underlying theoretical framework. The analysis yielded high factor loadings for all the items on the various factors underlying the scale (see table 11). All factor loadings were found to be statistically significant $(\mathrm{p}<.001)$.

Table 11. Information Quality Factors scale confirmatory factor analysis standardised item factor loadings $(n=128)$

\begin{tabular}{|c|c|c|c|c|c|c|}
\hline Item & Scale & $\begin{array}{l}\text { Personalis- } \\
\text { ation }\end{array}$ & $\begin{array}{l}\text { Complete- } \\
\text { ness }\end{array}$ & Relevancy & $\begin{array}{l}\text { Ease of } \\
\text { Understanding }\end{array}$ & Secureness \\
\hline 1 & Personalisation & .888 & & & & \\
\hline 2 & Personalisation & .933 & & & & \\
\hline 3 & Personalisation & .791 & & & & \\
\hline 4 & Personalisation & .619 & & & & \\
\hline 5 & Completeness & & .704 & & & \\
\hline 6 & Completeness & & .890 & & & \\
\hline 7 & Completeness & & .523 & & & \\
\hline 8 & Relevancy & & & .703 & & \\
\hline 9 & Relevancy & & & .702 & & \\
\hline 10 & Relevancy & & & .817 & & \\
\hline 11 & Relevancy & & & .727 & & \\
\hline 12 & Relevancy & & & .762 & & \\
\hline 13 & $\begin{array}{l}\text { Ease of } \\
\text { Understanding }\end{array}$ & & & & .801 & \\
\hline 14 & $\begin{array}{l}\text { Ease of } \\
\text { Understanding }\end{array}$ & & & & .801 & \\
\hline 15 & $\begin{array}{l}\text { Ease of } \\
\text { Understanding }\end{array}$ & & & & .917 & \\
\hline 16 & $\begin{array}{l}\text { Ease of } \\
\text { Understanding }\end{array}$ & & & & .932 & \\
\hline 17 & $\begin{array}{l}\text { Ease of } \\
\text { Understanding }\end{array}$ & & & & .820 & \\
\hline 18 & $\begin{array}{l}\text { Ease of } \\
\text { Understanding }\end{array}$ & & & & .736 & \\
\hline 19 & Secureness & & & & & .846 \\
\hline 20 & Secureness & & & & & .789 \\
\hline 21 & Secureness & & & & & .932 \\
\hline 22 & Secureness & & & & & .777 \\
\hline 23 & Secureness & & & & & .503 \\
\hline
\end{tabular}

Note: All factor loadings were found to be statistically significant $(\mathrm{p}<.05)$.

Source: Author's own research results.

Despite the high factor loadings, the overall fit of the hypothesised model was found to be problematic. Overall the chi-square test was found to be significant with $x^{2}(215)=388.555, \mathrm{p}<.001$, indicating poor fit. Further fit indices also indicated poor fit of the model with the GFI $=.795(<.95)$, CFI $=.914(<.95)$ and the RMSEA $=.081(>.8)$ (see table 4). Overall the model thus did not fit the data.

Table 12. Information Quality Factors scale goodness-of-fit indices

\begin{tabular}{|l|l|l|l|l|l|l|}
\hline Model & $\boldsymbol{x}^{2}$ & $\boldsymbol{d} \boldsymbol{f}$ & $\boldsymbol{p}$ & GFI & CFI & RMSEA \\
\hline
\end{tabular}




\begin{tabular}{|l|l|l|l|l|l|l|}
\hline Original model & 388.555 & 215 & $<.001$ & .795 & .914 & .081 \\
\hline
\end{tabular}

In examining the correlations between the various factors in the model, strong relationships between the different factors within the model was found with only 'Personalisation' and 'Secureness' not correlating highly within the posited model. All other correlations ranged from moderate positive $(\geq .3)$ to strong $(\geq .5)$ and very strong $(\geq$.7) positive correlations. Strong relationships thus exist between the various dimensions underlying the model. Table 13 below provides a breakdown of the correlations between the factors.

Table 13. Factor correlation matrix for Information Quality Factors scale

\begin{tabular}{|c|c|c|c|c|c|}
\hline Factor & Personalisation & Completeness & Relevancy & $\begin{array}{l}\text { Ease of } \\
\text { Understanding }\end{array}$ & Secureness \\
\hline Personalisation & 1 & & & & \\
\hline Completeness & .402 & 1 & & & \\
\hline Relevancy & .400 & .750 & 1 & & \\
\hline $\begin{array}{l}\text { Ease of } \\
\text { Understanding }\end{array}$ & .327 & .586 & .807 & 1 & \\
\hline Secureness & .154 & .456 & .543 & .491 & 1 \\
\hline
\end{tabular}

Source: Author's own research results.

Exploratory factor analysis - Information Quality Factors scale

In order to further explore the underlying dimensionality of the Information Quality Factors scale in light of the findings of the confirmatory factor analysis; alternative exploratory factor analysis was conducted on the data.

Table 14. KMO and Bartlett's test of sphericity statistics for Information Quality Factors scale

\begin{tabular}{|c|c|c|}
\hline \multicolumn{2}{|c|}{ Kaiser-Meyer-Olkin measure of Sampling Adequacy } & .870 \\
\hline Bartlett's Test of Sphericity & $\begin{array}{l}\text { Apprx. Chi-Square } \\
\text { df } \\
\text { Sig. }\end{array}$ & $\begin{array}{l}2121.276 \\
253 \\
.000\end{array}$ \\
\hline
\end{tabular}

Source: Author's own research results.

The Kaiser-Meyer-Olkin (KMO) measure of sampling adequacy as well as the Bartlett's test of sphericity was utilised to determine the factorability of the data. Both the KMO measure (.870) and the Bartlett's test of sphericity $x^{2}(253)=2121.276, \mathrm{p}<$ .01 , suggested sufficient inter-correlation and common variance within the data to conduct a factor analysis (see table 14).

The Kaiser-criterion (eigenvalues-greater-than 1) as well as the scree-plot suggested the extraction of four factors (see figure 2). Although the a priori criterion, in line with the posited theoretical framework underlying the scale, stipulates five factors, the lack of stable factors, cross-loading of items in the five factor model and difficulty in interpreting factors, further supported the decision to extract four factors. 


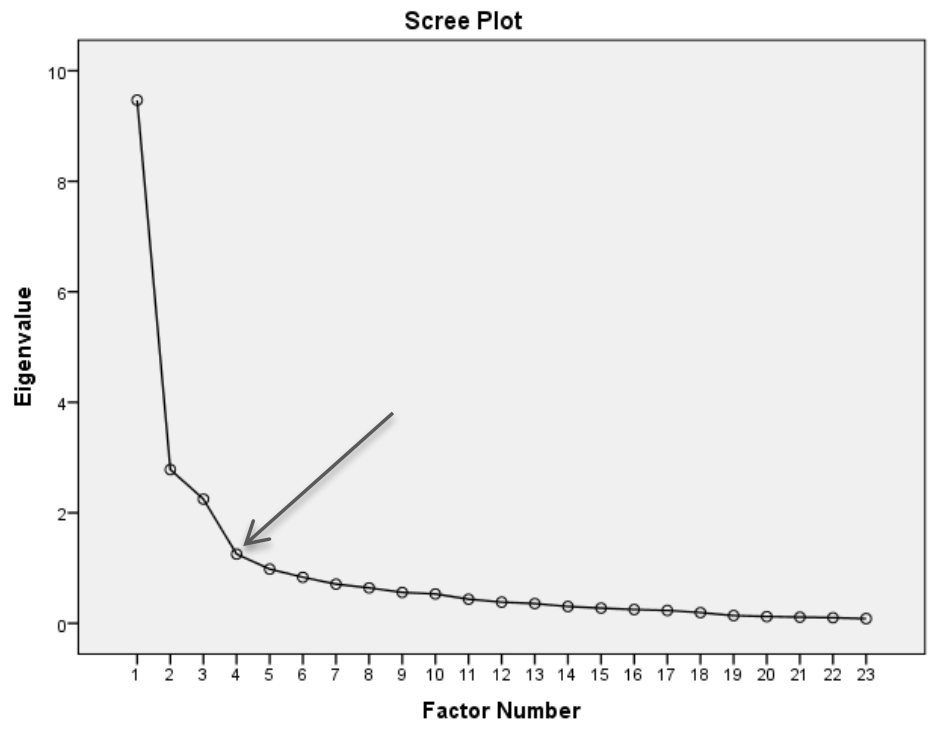

Figure 2. Scree-plot Information Quality Factors scale

Source: Author's own research results.

Table 15 provides the pattern matrix for the final factor solution after rotation. Only item 12 and item 9 did not load significantly $(<.4)$ onto any of the factors (see table 15).

Table 15. Pattern matrix (rotated factor matrix) Information Quality Factors scale

\begin{tabular}{|l|l|l|l|l|}
\hline \multirow{2}{*}{ Items } & \multicolumn{4}{|c|}{ Factor } \\
\cline { 2 - 5 } $\mathbf{1 5}$ & $\mathbf{1}$ & $\mathbf{2}$ & $\mathbf{3}$ & $\mathbf{4}$ \\
$\mathbf{1 6}$ & .817 & & & \\
$\mathbf{1 8}$ & .801 & & & \\
$\mathbf{1 7}$ & .786 & & & \\
$\mathbf{1 4}$ & .686 & & & \\
$\mathbf{1 3}$ & .621 & & & \\
$\mathbf{2}$ & & .972 & & \\
$\mathbf{1}$ & & .848 & & \\
$\mathbf{3}$ & & .798 & & \\
$\mathbf{4}$ & & .552 & & \\
$\mathbf{1 9}$ & & & .854 & \\
$\mathbf{2 1}$ & & & .833 & \\
$\mathbf{2 0}$ & & & .808 & \\
$\mathbf{2 2}$ & & & .798 & \\
$\mathbf{2 3}$ & & & .566 & \\
$\mathbf{6}$ & & & & .709 \\
$\mathbf{5}$ & & & & .652 \\
$\mathbf{1 1}$ & & & & .612 \\
$\mathbf{1 0}$ & & & & .473 \\
$\mathbf{8}$ & & & & .438 \\
$\mathbf{7}$ & & & & \\
$\mathbf{1 2}$ & & & & \\
$\mathbf{9}$ & & & & \\
\hline
\end{tabular}

Source: Author's own research results.

From the pattern matrix the following table (table 16) provides a summarised version of the various items which loaded onto the different factors. 
Table 16. Significant items per factors extracted Information Quality Factors scale

\begin{tabular}{|c|c|c|}
\hline & Factor 1 & \\
\hline Item & Content & Loading \\
\hline 13 & $\begin{array}{l}\text { A shopping site that provides information that is easy to understand influences me to } \\
\text { shop online. }\end{array}$ & .621 \\
\hline 14 & A shopping site that provides clear instructions influences me to shop online. & 686 \\
\hline 15 & A shopping site that provides information that is simple influences me to shop online. & 917 \\
\hline 16 & $\begin{array}{l}\text { A shopping site that provides information that is easy to read influences me to shop } \\
\text { online. }\end{array}$ & .882 \\
\hline 17 & $\begin{array}{l}\text { A shopping site that provides information that is straight to the point influences me } \\
\text { to shop online. }\end{array}$ & .786 \\
\hline \multirow[t]{2}{*}{18} & $\begin{array}{l}\text { A shopping site that provides information that is clear in meaning influences me to } \\
\text { shop online. }\end{array}$ & .801 \\
\hline & Factor 2 & \\
\hline Item & Content & Loading \\
\hline 1 & $\begin{array}{l}\text { A shopping site that suggests products/services based on my interests influences me } \\
\text { to shop online. }\end{array}$ & .848 \\
\hline 2 & $\begin{array}{l}\text { A shopping site that suggests products/services I am likely to buy influences me to } \\
\text { shop online. }\end{array}$ & .972 \\
\hline 3 & $\begin{array}{l}\text { A shopping site that suggests products/services based on my purchasing history } \\
\text { influences me to shop online. }\end{array}$ & .798 \\
\hline \multirow[t]{2}{*}{4} & $\begin{array}{l}\text { A shopping site that provides accurate recommendations as to what I am looking for } \\
\text { influences me to shop online. }\end{array}$ & .552 \\
\hline & Factor 3 & \\
\hline Item & Content & Loading \\
\hline 19 & A shopping site that has secure methods of payment influences me to shop online. & .854 \\
\hline 20 & $\begin{array}{l}\text { A shopping site that protects my credit/debit card details influences me to shop } \\
\text { online. }\end{array}$ & .808 \\
\hline 21 & A shopping site that has privacy policies in place influences me to shop online. & .833 \\
\hline 22 & A shopping site that protects my personal information influences me to shop online. & .798 \\
\hline \multirow[t]{2}{*}{23} & $\begin{array}{l}\text { A shopping site that prevents unlawful use of my information influences me to shop } \\
\text { online. }\end{array}$ & .566 \\
\hline & Factor 4 & \\
\hline Item & Content & Loading \\
\hline 5 & $\begin{array}{l}\text { A shopping site that provides comprehensive information on their products/services } \\
\text { influences me to shop online. }\end{array}$ & .652 \\
\hline 6 & $\begin{array}{l}\text { A shopping site that provides comprehensive information on their shopping process } \\
\text { influences me to shop online. }\end{array}$ & .709 \\
\hline 7 & $\begin{array}{l}\text { A shopping site that provides comprehensive information about the company } \\
\text { influences me to shop online. }\end{array}$ & .425 \\
\hline 8 & $\begin{array}{l}\text { A shopping site that provides all the relevant information I need influences me to } \\
\text { shop online. }\end{array}$ & .438 \\
\hline 10 & $\begin{array}{l}\text { A shopping site that provides relevant information on their products/services } \\
\text { influences me to shop online. }\end{array}$ & .473 \\
\hline 11 & $\begin{array}{l}\text { A shopping site that provides up-to-date information on their products/services } \\
\text { influences me to shop online. }\end{array}$ & .612 \\
\hline
\end{tabular}

Source: Author's own research results.

Factor 1 was constituted predominantly from items related to clear, simple and easy to read information with regard to online shopping. The highest loading item on the factor was 'A shopping site that provides information that is simple influences me to shop online', and thus the factor was labelled 'Ease of Understanding' (see table 16).

Items which loaded significantly onto Factor 2 were related to interests and preferences of the individual when shopping online with the highest loading item being 'A shopping site that suggests products/services I am likely to buy influences me to shop online'. The factor was subsequently labelled 'Personalisation' (see table 16). 
The items which loaded significantly onto Factor 3 relate primarily to elements regarding security in relation to online shopping. 'A shopping site that has secure methods of payment influences me to shop online', was the highest loading item and thus the factor was labelled as 'Secureness' (see table 16).

The final factor contained items which relate to both comprehensive information as well as relevant and up-to-date information. The highest loading item was 'A shopping site that provides comprehensive information on their shopping process influences me to shop online'. Considering the importance of both the element of comprehensiveness or completeness of information as well as the relevancy of information, the factor was labelled 'Completeness and Relevancy' (see table 16).

In line with the findings from the confirmatory factor analysis, moderate positive correlations $(\geq .3)$ to strong positive correlations $(\geq .5)$ were found between the extracted factors, except for the factors 'Personalisation' and 'Secureness' (see table 17).

Table 17. Factor correlation matrix for Information Quality Factors scale (exploratory)

\begin{tabular}{|l|l|l|l|l|}
\hline & Factor 1 & Factor 2 & Factor 3 & Factor 4 \\
\hline Factor 1 & 1 & & & \\
Factor 2 & .250 & 1 & & \\
Factor 3 & .372 & .123 & 1 & \\
Factor 4 & .551 & .408 & .384 & 1 \\
\hline
\end{tabular}

Source: Author's own research results.

In line with the factor analyses, Cronbach's Alpha reliability coefficients were calculated for each of the factors identified. Table 18 below shows that all the factors/subscales showed good internal consistency and reliability with all the Cronbach's Alpha coefficients > 0.6 (Field, 2005; Hair, Black, Babin \& Anderson, 2010).

Table 18. Cronbach's alpha coefficients per factor Information Quality Factors scale

\begin{tabular}{|l|l|l|}
\hline & Label & Cronbach's Alpha \\
\hline Factor 1 & Ease of Understanding & .935 \\
Factor 2 & Personalisation & .888 \\
Factor 3 & Secureness & .877 \\
Factor 4 & Completeness \& Relevancy & .819 \\
\hline
\end{tabular}

Source: Author's own research results.

\section{Service Quality Factors scale}

Confirmatory factor analysis - Service Quality Factors scale

Based on the underlying theoretical framework, a five-factor model was utilised in the confirmatory factor analysis of the Service Quality Factors scale. All the items in the analysis loaded highly on the various factors with all factor loadings being significant ( $p$ $<.001$ ). Item 26 was the only exception with a small factor loading of .266, yet this was still found to be significant $(\mathrm{p}<.01)$ (see table 19).

Table 19. Service Quality Factors scale confirmatory factor analysis standardised item factor loadings $(n=128)$

\begin{tabular}{|c|l|l|l|l|l|l|}
\hline Item & Scale & Responsiveness & Assurance & Empathy & Reliability & $\begin{array}{l}\text { Follow-up } \\
\text { Service }\end{array}$ \\
\hline $\mathbf{1}$ & Responsiveness & .656 & & & & \\
$\mathbf{2}$ & Responsiveness & .864 & & & & \\
\hline
\end{tabular}




\begin{tabular}{|c|c|c|c|c|c|c|}
\hline Item & Scale & Responsiveness & Assurance & Empathy & Reliability & $\begin{array}{l}\text { Follow-up } \\
\text { Service }\end{array}$ \\
\hline 3 & Responsiveness & .895 & & & & \\
\hline 4 & Responsiveness & .879 & & & & \\
\hline 5 & Responsiveness & .882 & & & & \\
\hline 6 & Assurance & & .768 & & & \\
\hline 7 & Assurance & & .695 & & & \\
\hline 8 & Assurance & & .747 & & & \\
\hline 9 & Assurance & & .385 & & & \\
\hline 10 & Assurance & & .794 & & & \\
\hline 11 & Assurance & & .719 & & & \\
\hline 12 & Empathy & & & .709 & & \\
\hline 13 & Empathy & & & .794 & & \\
\hline 14 & Empathy & & & .891 & & \\
\hline 15 & Empathy & & & .627 & & \\
\hline 16 & Reliability & & & & .812 & \\
\hline 17 & Reliability & & & & .741 & \\
\hline 18 & Reliability & & & & .895 & \\
\hline 19 & Reliability & & & & .855 & \\
\hline 20 & Reliability & & & & .861 & \\
\hline 21 & Reliability & & & & .889 & \\
\hline 22 & $\begin{array}{l}\text { Follow-up } \\
\text { Service }\end{array}$ & & & & & \\
\hline 23 & $\begin{array}{l}\text { Follow-up } \\
\text { Service }\end{array}$ & & & & & .496 \\
\hline 24 & $\begin{array}{l}\text { Follow-up } \\
\text { Service }\end{array}$ & & & & & .951 \\
\hline 25 & $\begin{array}{l}\text { Follow-up } \\
\text { Service }\end{array}$ & & & & & .942 \\
\hline 26 & $\begin{array}{l}\text { Follow-up } \\
\text { Service }\end{array}$ & & & & & .266 \\
\hline
\end{tabular}

Source: Author's own research results.

Overall the hypothesised model did not fit the data well. The chi-square test was significant, $x^{2}(282)=648.454, \mathrm{p}<.001$, indicating poor fit. The additional goodness-offit indices also suggested poor fit for the model with the GFI $=.739(<.95), \mathrm{CFI}=.854(<$ .95 ) and the RMSEA = .103 (> .8) (see table 20).

Table 20. Service Quality Factors scale goodness-of-fit indices

\begin{tabular}{|l|l|l|l|l|l|l|}
\hline Model & $\boldsymbol{x}^{\mathbf{2}}$ & $\boldsymbol{d} \boldsymbol{f}$ & $\boldsymbol{p}$ & GFI & CFI & RMSEA \\
\hline Original model & 648.454 & 282 & $<.001$ & .739 & .854 & .103 \\
\hline
\end{tabular}

Strong relationships were found between the factors present in the model with moderate $(\geq .3)$ to strong $(\geq .5)$ and very strong $(\geq .7)$ positive correlations found between the majority of the factors (see table 13). Weak positive correlations $(<.3$ ) however were found between 'Follow-up Service' and the other factors in the model, with almost no correlation between 'Follow-up Service' and 'Reliability' (see table 21).

Table 21. Factor correlation matrix for Service Quality Factors scale

\begin{tabular}{|l|l|l|l|l} 
Responsiveness & Assurance & Empathy & Reliability & Follow-up
\end{tabular}




\begin{tabular}{|l|l|l|l|l|l|}
\hline & & & & & Service \\
\hline Responsiveness & 1 & & & & \\
Assurance & .822 & 1 & & & \\
Empathy & .821 & .754 & 1 & & \\
Reliability & .785 & .874 & .735 & 1 & 1 \\
Follow-up & .263 & .247 & .205 & .095 & \\
Service & & & & & \\
\hline
\end{tabular}

Source: Author's own research results.

Exploratory factor analysis - Service Quality Factors scale

The dimensionality of the Service Quality Factors scale following the results of the confirmatory factor analysis was further investigated by conducting an exploratory factor analysis.

Table 22. KMO and Bartlett's test of sphericity statistics for Service Quality Factors scale

\begin{tabular}{|ll|l|}
\hline Kaiser-Meyer-Olkin measure of Sampling Adequacy & .888 \\
\hline Bartlett's Test of Sphericity & Apprx. Chi-Square & 2621.553 \\
& df & 325 \\
Sig. & .000 \\
\hline
\end{tabular}

Source: Author's own research results.

The KMO measure (.888) and the Bartlett's test of sphericity $x^{2}(325)=2621.553$, $\mathrm{p}<.01$, suggested sufficient inter-correlation and common variance within the data to conduct an exploratory factor analysis (see table 22).

In terms of the number of factors to extract, the Kaiser-criterion (eigenvaluesgreater-than 1) suggested the extraction of five factors, in line with the a priori criterion. This however resulted in two unstable factors (less than 3 significant loadings per factor) as well as cross-loadings of items on more than one factor (see table 23). Consequently the extraction of four factors was also investigated, again yielding unstable factors (see table 24). Finally, in examining the scree-plot (see figure 3), the decision was made to extract three factors in order to ensure the interpretability and stability of the resulting factors.

Table 23. Pattern matrix (rotated factor matrix) Service Quality Factors scale - 5 factors

\begin{tabular}{|c|c|c|c|c|c|}
\hline \multirow{2}{*}{ Items } & \multicolumn{4}{|c|}{ Factor } & \\
\hline & 1 & 2 & 3 & 4 & 5 \\
\hline 19 & .814 & & & & \\
\hline 21 & .791 & & & & \\
\hline 18 & .789 & & & & \\
\hline 20 & .782 & & & & \\
\hline 10 & .744 & & & & \\
\hline 26 & .737 & & & & \\
\hline 1 & .632 & & & & \\
\hline 17 & .564 & & & & \\
\hline 11 & .505 & & & & \\
\hline 8 & .495 & & & & \\
\hline 16 & .471 & & .432 & & \\
\hline 7 & .403 & & & & \\
\hline 24 & & .992 & & & \\
\hline 25 & & 895 & & & \\
\hline 13 & & & .740 & & \\
\hline 14 & & & .723 & & \\
\hline
\end{tabular}




\begin{tabular}{|l|l|l|l|l|l|}
\hline \multirow{2}{*}{ Items } & \multicolumn{4}{|l|}{ Factor } & \multicolumn{3}{l|}{} & \\
\cline { 2 - 6 } & $\mathbf{1}$ & $\mathbf{2}$ & $\mathbf{3}$ & $\mathbf{4}$ & $\mathbf{5}$ \\
\hline $\mathbf{1 2}$ & & & .651 & & \\
$\mathbf{3}$ & & & .458 & & .438 \\
$\mathbf{1 5}$ & & & & & \\
$\mathbf{9}$ & & & & & \\
$\mathbf{2 3}$ & & & & .556 & \\
$\mathbf{2 2}$ & & & & .420 & \\
$\mathbf{2}$ & & & & & .653 \\
$\mathbf{5}$ & & & & & .615 \\
$\mathbf{6}$ & & & & & .574 \\
$\mathbf{4}$ & & & & & .567 \\
\hline
\end{tabular}

Source: Author's own research results.

Table 24. Pattern matrix (rotated factor matrix) Service Quality Factors scale - 4 factors

\begin{tabular}{|l|l|l|l|l|}
\hline \multirow{2}{*}{ Items } & \multicolumn{2}{|l|}{ Factor } \\
\cline { 2 - 5 } & $\mathbf{1}$ & $\mathbf{2}$ & $\mathbf{3}$ & $\mathbf{4}$ \\
\hline $\mathbf{2 1}$ & .882 & & & \\
$\mathbf{1 9}$ & .867 & & & \\
$\mathbf{1 8}$ & .847 & & & \\
$\mathbf{2 0}$ & .841 & & & \\
$\mathbf{1 0}$ & .775 & & & \\
$\mathbf{2 6}$ & .720 & & & \\
$\mathbf{1}$ & .689 & & & \\
$\mathbf{1 7}$ & .607 & & & \\
$\mathbf{8}$ & .580 & & & \\
$\mathbf{1 1}$ & .556 & & & \\
$\mathbf{7}$ & .509 & & & \\
$\mathbf{1 6}$ & .499 & & & \\
$\mathbf{6}$ & .407 & & & \\
$\mathbf{2 4}$ & & .980 & & \\
$\mathbf{2 5}$ & & .932 & & \\
$\mathbf{9}$ & & & .855 & \\
$\mathbf{3}$ & & & .794 & \\
$\mathbf{1 4}$ & & & .780 & \\
$\mathbf{1 3}$ & & & .768 & \\
$\mathbf{4}$ & & & .669 & \\
$\mathbf{2}$ & & & .635 & \\
$\mathbf{1 2}$ & & & .461 & \\
$\mathbf{1 5}$ & & & & \\
$\mathbf{5}$ & .427 & & & \\
$\mathbf{2 3}$ & & & & \\
$\mathbf{2 2}$ & & & & \\
\end{tabular}

Source: Author's own research results. 


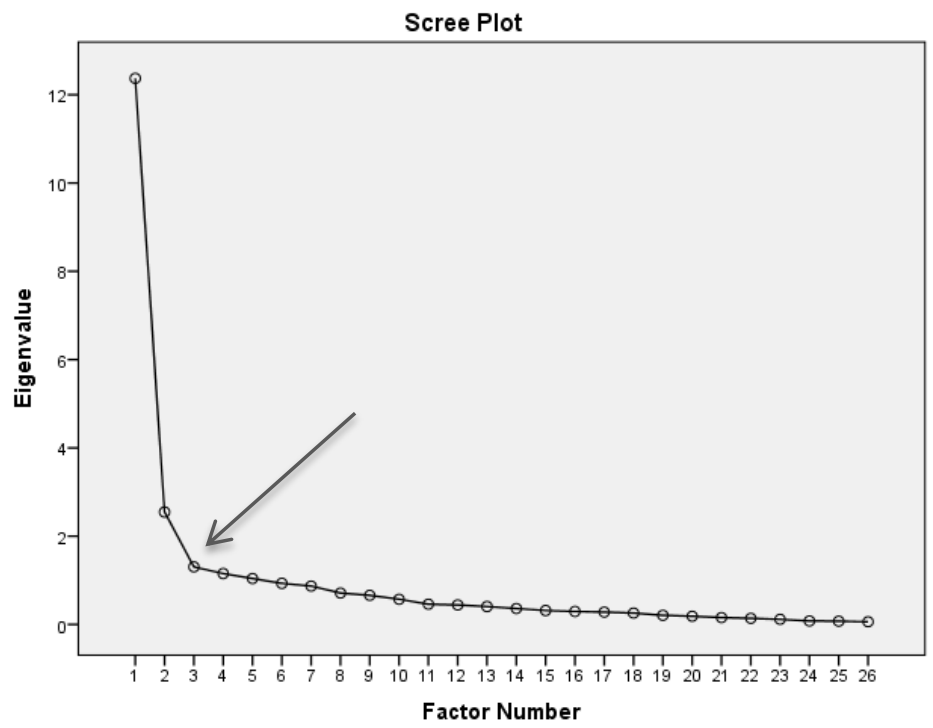

Figure 3. Scree-plot Service Quality Factors scale

Source: Author's own research results.

Table 25 below provides the pattern matrix for the final factor solution with three factors extracted. Items 9 and 22 did not load significantly $(<.4)$ on any of the factors with item 5 cross-loading on both Factor 1 and Factor 3 (see table 25).

Table 25. Pattern matrix (rotated factor matrix) Service Quality Factors scale - 3 factors

\begin{tabular}{|l|l|l|l|}
\hline \multirow{2}{*}{ Items } & \multicolumn{3}{|c|}{ Factor } \\
\cline { 2 - 4 } $\mathbf{1}$ & $\mathbf{2}$ & $\mathbf{3}$ \\
\hline $\mathbf{2 1}$ & .923 & & \\
$\mathbf{1 9}$ & .877 & & \\
$\mathbf{1 8}$ & .845 & & \\
$\mathbf{2 0}$ & .825 & & \\
$\mathbf{1 0}$ & .807 & & \\
$\mathbf{1 7}$ & .678 & & \\
$\mathbf{8}$ & .653 & & \\
$\mathbf{1 6}$ & .610 & & \\
$\mathbf{2 6}$ & .603 & & \\
$\mathbf{1}$ & .603 & & \\
$\mathbf{1 1}$ & .600 & & \\
$\mathbf{7}$ & .558 & & \\
$\mathbf{6}$ & .485 & & \\
$\mathbf{9}$ & & & \\
$\mathbf{2 4}$ & & .962 & \\
$\mathbf{2 5}$ & & .919 & \\
$\mathbf{2 3}$ & & .488 & \\
$\mathbf{3}$ & & & .887 \\
$\mathbf{4}$ & & & .771 \\
$\mathbf{1 3}$ & & & .757 \\
$\mathbf{2}$ & & & .705 \\
$\mathbf{1 4}$ & & & .701 \\
$\mathbf{1 5}$ & & & .455 \\
$\mathbf{1 2}$ & & & .451 \\
$\mathbf{5}$ & $.432^{*}$ & & $.446^{*}$ \\
$\mathbf{2 2}$ & & & \\
\hline
\end{tabular}

Source: Author's own research results. 
Table 26 provides a summary of the items which loaded significantly on the various factors.

Table 26. Significant items per factors extracted Service Quality Factors scale

\begin{tabular}{|c|c|c|}
\hline & Factor 1 & \\
\hline Item & Content & Loading \\
\hline 1 & An online retailer that provides prompt services influences me to shop online. & .603 \\
\hline 6 & An online retailer that is trustworthy influences me to shop online. & .485 \\
\hline 7 & An online retailer that goes out of their way to help me influences me to shop online. & .558 \\
\hline 8 & An online retailer that has a good reputation influences me to shop online. & 653 \\
\hline 10 & An online retailer that I am confident in influences me to shop online. & .807 \\
\hline 11 & An online retailer that is transparent (open and candid) influences me to shop online. & .600 \\
\hline 16 & An online retailer that ensures accurate transactions influences me to shop online. & .610 \\
\hline 17 & $\begin{array}{l}\text { An online retailer that keeps accurate records of purchases influences me to shop } \\
\text { online. }\end{array}$ & 678 \\
\hline 18 & $\begin{array}{l}\text { An online retailer that keeps to their fulfilment promises influences me to shop } \\
\text { online. }\end{array}$ & .845 \\
\hline 19 & $\begin{array}{l}\text { An online retailer that performs their services right the first time influences me to } \\
\text { shop online. }\end{array}$ & 877 \\
\hline 20 & An online retailer that is effective in providing services influences me to shop online. & 825 \\
\hline 21 & An online retailer that is efficient in providing services influences me to shop online. & .923 \\
\hline \multirow[t]{2}{*}{26} & $\begin{array}{l}\text { An online retailer that addresses issues if I am dissatisfied with the product/service, } \\
\text { influences me to shop online. }\end{array}$ & 603 \\
\hline & Factor 2 & \\
\hline Item & Content & Loading \\
\hline 23 & $\begin{array}{l}\text { An online retailer that follows up on abandoned purchases influences me to shop } \\
\text { online. }\end{array}$ & .488 \\
\hline 24 & An online retailer that encourages customer reviews influences me to shop online. & 962 \\
\hline \multirow[t]{2}{*}{25} & $\begin{array}{l}\text { An online retailer that encourages product/service ratings influences me to shop } \\
\text { online. }\end{array}$ & 919 \\
\hline & Factor 3 & \\
\hline Item & Content & Loading \\
\hline 2 & $\begin{array}{l}\text { An online retailer that provides assistance when I need it influences me to shop } \\
\text { online. }\end{array}$ & .705 \\
\hline 3 & An online retailer that provides guidance when I need it influences me to shop online. & 887 \\
\hline 4 & An online retailer that is willing to help when I need it influences me to shop online. & .771 \\
\hline 5 & $\begin{array}{l}\text { An online retailer that provides accurate information when I need it influences me to } \\
\text { shop online. }\end{array}$ & 446 \\
\hline 12 & $\begin{array}{l}\text { An online retailer that is empathetic towards my situation if something goes wrong } \\
\text { during the shopping process, influences me to shop online. }\end{array}$ & 451 \\
\hline 13 & $\begin{array}{l}\text { An online retailer that provides individualised solutions to my problems experienced } \\
\text { during the shopping process, influences me to shop online. }\end{array}$ & .757 \\
\hline 14 & $\begin{array}{l}\text { An online retailer that shows that they care about my situation if something goes } \\
\text { wrong during the shopping process, influences me to shop online. }\end{array}$ & 701 \\
\hline 15 & $\begin{array}{l}\text { An online retailer that gives personalised responses instead of generic auto-replies } \\
\text { influences me to shop online. }\end{array}$ & .455 \\
\hline
\end{tabular}

Source: Author's own research results.

Factor 1 consists of items which relate to the efficiency and reliability of services from online retailers along with confidence or trust in online retailers. The highest loading items on the factor were 'An online retailer that performs their services right the first time influences me to shop online', 'An online retailer that is efficient in providing services influences me to shop online' and 'An online retailer that keeps to their fulfilment promises influences me to shop online'. Considering the elements of reliability and the notion of efficiency associated with this, along with the element of 
confidence and trust contained within the content of the items, the factor was labelled 'Efficiency \& Assurance' (see table 26).

Items which load significantly onto Factor 2 relate primarily to customer inputs in terms of reviews and ratings of services in the light of follow-up service. The highest loading items on the scale were 'An online retailer that encourages customer reviews influences me to shop online' and 'An online retailer that encourages product/service ratings influences me to shop online'. The factor was thus labelled 'Follow-up Service' (see table 26).

The final factor consisted of items relating to the provision of support and guidance by online retailers as well as online retailers displaying empathy and care. This is further coupled with the notion of an individualised/personalised approach by online retailers. Items which loaded the highest on the factor were 'An online retailer that provides guidance when I need it influences me to shop online', 'An online retailer that is willing to help when I need it influences me to shop online' and 'An online retailer that provides individualised solutions to my problems experienced during the shopping process, influences me to shop online'. Taking the various elements of the item content into account, with support and guidance coupled with empathy and care, the factor was labelled 'Responsiveness \& Empathy' (see table 26).

In terms of correlation between the factors, a very strong positive correlation $(\geq$ .7) was found between Factor 1 (Efficiency \& Assurance) and Factor 3 (Responsiveness \& Empathy), with a moderate positive correlation $(\geq .3$ ) between Factor 2 (Follow-up Service) and Factor 3 (Responsiveness \& Empathy). Only a weak positive correlation was found between Factor 1 (Efficiency \& Assurance) and Factor 2 (Follow-up Service) (see table 27).

Table 27. Factor correlation matrix for Service Quality Factors scale (exploratory)

\begin{tabular}{|l|l|l|l|}
\hline & Factor 1 & Factor 2 & Factor 3 \\
\hline Factor 1 & 1 & & \\
Factor 2 & .163 & 1 & \\
Factor 3 & .742 & .304 & 1 \\
\hline
\end{tabular}

Source: Author's own research results.

Table 28 below provides the Cronbach's Alpha reliability coefficients for each of the factors identified. All the factors showed good internal consistency and reliability with all the Cronbach's Alpha coefficients > 0.6 (Field, 2005; Hair, Black, Babin \& Anderson, 2010).

Table 28. Cronbach's alpha coefficients per factor Service Quality Factors scale

\begin{tabular}{|l|l|l|}
\hline & Label & $\begin{array}{l}\text { Cronbach's } \\
\text { Alpha }\end{array}$ \\
\hline Factor 1 & Efficiency \& Assurance & .942 \\
Factor 2 & Follow-up Service & .811 \\
Factor 3 & Responsiveness \& Empathy & .918 \\
\hline
\end{tabular}

Source: Author's own research results

\section{Discussion}

From the data it is clear that the original hypothesised models for all three scales did not provide an adequate fit for the data. Findings from the confirmatory factor analyses indicated that model fit for the Information Quality Factors scale, the System Quality 
Factors scale and the Service Quality Factors scale was problematic, despite significant factor loadings which were deceptively high for each of the respective scales. Although the Information Quality scale and the System Quality scale were close in achieving adequate fit, they still did not meet the fit criteria.

In investigating the further dimensionality of the respective scales through exploratory factor analyses, both the Information Quality Factors scale and the System Quality Factors scale yielded a similar factor structure to the original hypothesised model as was used in the confirmatory factor analyses. Instead of a theorised five-factor structure, the scales yielded a four-factor structure with the originally hypothesised factors largely being maintained. The fourth factor in both these scales, following the exploratory factor analyses, was a combination between two of the dimensions in the original hypothesised model.

With regards to the Service Quality Factors scale, the exploratory factor analyses revealed a slightly altered dimensionality than the original hypothesised model used in the confirmatory factor analysis. Three factors emerged from the analysis which ultimately stemmed from a combination of the original factors in the hypothesised model. With closer examination it is clear that the extracted factors still reflect the underlying theory, yet poignantly illuminates the relationships between the various factors/elements. 'Responsiveness \& Empathy,' for example, emerged as a factor following the exploratory factor analyses. While these elements were separated in the original hypothesised model into separate factors, the fact that they ultimately emerged as elements of the same dimension may allude to the fact that while online shoppers want support and guidance, they also want this support and guidance to be individualised and to be empathetic. Similar arguments can be made for the other factors which resulted from the exploratory factor analyses.

Overall, strong relationships were found between the various factors underlying the hypothesised models in the confirmatory factor analyses as well as the extracted factors in the exploratory factor analyses. While this may be the case, if the item content is examined in line with the underlying theoretical framework, this makes sense both practically and theoretically.

Finally, although the confirmatory factor analyses confirmed a poor fit for the hypothesised models for each of the examined scales respectively, the exploratory factor analyses seemed to support the basic underlying theoretical framework for the model with slight adjustments to the original postulation and dimensionality, yet with the basic elements of the theoretical framework largely maintained to some degree.

\section{Limitations}

The primary limitation of the study centres around the sample included. Firstly, due to the utilisation of convenience sampling, the sample consists predominantly of respondents from the Gauteng area and respondents with a higher level of qualification. The results from the study may thus not be applied to the broader South African population. The lack of demographic data regarding the racial distribution of the sample may further restrict the generalisation of the results.

Secondly, the sample size in the study, in light of the statistical methods utilised, may also warrant some consideration. While the minimum requirements with regards to sample size were met for both the confirmatory factor analyses (minimum sample size $=100$ with $\leq 5$ constructs, each with more than 3 items and high communalities) as well as the exploratory factor analyses (sample size $=$ to 5 respondents per item) and 
the effect of sample size was somewhat controlled for by the use of more stringent cutoff criteria in terms of fit and significant factor loadings, a larger sample may provide more stable solutions (Field, 2005; Hair et al., 2010; Hu and Bentler, 1995, 1998, 1999).

\section{Conclusion}

This study contributes online shopping literature relating to quality factors influencing online shopping; particularly from a South African perspective. The study provides a general outline for online retailers operating in South Africa on the quality factors that should be taken into consideration with regards to their shopping website. The study examined the construct validity of three respective scales related to website quality factors, namely; the System Quality Factors scale, the Information Quality Factors scale and the Service Quality Factors scale. While the confirmatory factor analyses found poor fit for the original hypothesised models for each of the scales, further exploratory factor analyses revealed slightly different dimensionalities underlying the scales, yet these were still somewhat aligned with the theoretical framework from which the original scales were derived. Ultimately the study found that the construct validity of the scales in their current form were problematic. Based on the results, it is clear that the dimensionality underlying the System Quality Factors scale, the Information Quality Factors scale and the Service Quality Factors scale warrants further investigation. The results from the study provide an initial platform for the revision of original scales to be further tested on a larger, representative sample to ensure the construct validity of the scales, the generalisation of the findings and ultimately the development of valid scales to measure System Quality Factors, Information Quality Factors and Service Quality Factors in relation to website quality factors in the online shopping environment. In conclusion,

\section{References}

Afshardost, M., Farahmandian, S. \& SaqiqEshaghi, S.M. (2013), "Linking trust, perceived website quality, privacy protection, gender and online purchase intentions", IOSR Journal of Business and Management, Vol. 13, No. 4, pp. 63-72.

Al-Debei, M.M., Akroush, M.N., \& Ashouri, M.I. (2014), "Consumer attitudes towards online shopping: the effects of trust, perceived benefits, and perceived web quality", Internet Research, Vol. 25, No. 5, pp. 707-733.

Al-Mamary, Y.H., Shamsuddin, A. \& Aziati, N. (2013), "The impact of management information systems adoption in managerial decision making: a review", Management Information Systems, Vol. 8, No. 2013, pp. 10-17.

Al-Manasra, E.A., Khair, M., Zaid, S.A. \& Qutaishat, F.T. (2013), "Investigating the impact of website quality on consumers' satisfaction in Jordanian telecommunication section", Arab Economic and Business Journal, Vol. 8, pp. 31-37.

Alharbi, I.M., Zyngier, S. \& Hodkinson, C. (2013), "Privacy by design and customers' privacy and security concerns in the success of e-commerce", Journal of Enterprise Information Management, Vol. 26, No. 6, pp. 702-718.

Alrawashdeh, T.A., Muhairat, M. \& Althunibat, A. (2013), "Evaluating the quality of software in ERP systems using ISO 9126 model", International Journal of Ambient Systems and Applications, Vol 1, No 1, pp. 1-9.

Andersen, K. \& Gronau, N. (2007), "Criteria to assess the adaptability of software engineering approaches", IRMA International Conference, pp. 1460-1461.

Barnes, S. \& Vidgen, R. (2002), "An integrative approach to the assessment of e-commerce quality", Journal of Electronic Commerce Research, Vol. 3, No. 3, pp. 114-127. 
Bilgihan, A. and Bujisic, M. (2014), "The effect of website features in online relationship marketing: a case of online hotel booking", Electronic Commerce Research and Applications, Vol. 2014, pp. 1-11.

Brown, I. \& Jayakody, R. (2008), "B2C e-commerce success: A test and validation of a revised conceptual model”, Electronic Journal Information Systems Evaluation, Vol. 11, No. 3, pp. 167-184.

Cebi, S. (2013), "A quality evaluation model for the design quality of online shopping websites", Electronic Commerce Research and Application, Vol. 12, pp. 124-135.

Chen, C.W.D. \& Cheng, C.Y.J. (2009), "Understanding consumer intention in online shopping: A respecification and validation of the DeLone and McLean model", Behaviour and Information Technology, Vol. 28, No. 4, pp. 335-345.

Chiu, C., Wang, E.T.G., Fang, Y. Huang, H. (2012), "Understanding customers' repeat purchase intentions in B2C e-commerce: the role of utilitarian value, hedonic value and perceived risk", Information Systems Journal, Vol. 24, No. 1, pp. 85-114.

Coker, B. (2013), "Antecedents to website satisfaction, loyalty and word-of-mouth", Journal of Information Systems and Technology Management, Vol. 10, No. 2, pp. 209-218.

Daniel, C. \& Berinyuy, L. (2010), "Using SERVQUAL model to assess service quality and customer satisfaction", Graduate thesis, Umea School of Business, Sweden.

DeLone, W.H. \& McLean, E.R. (2003), "The DeLone and McLean model of information systems success: a ten-year update", Journal of Management Information Systems, Vol. 19, No. 4, pp. 9-30.

Field, A. (2005), "Discovering statistics using SPSS", 2nd edition, London: Sage Publications.

Gao, X. (2013), "The influence of mobile website quality on consumer satisfaction and behaviour", Graduate thesis, University of Nebraska.

Hair, J.F., Black, W.C., Babin, B.J. \& Anderson, R.E. (2010), “Multivariate data analyses: A global perspective", 7th edition, New Jersey: Pearson Prentice Hall.

Hamid, N.A.A. (2008), "The relative importance of trust and usable website design in building eloyalty intention on internet banking", Communications of the IBIMA, Vol. 3, No. 2008, pp. 101-113.

Hanai, T. \& Oguchi, T. (2009), "How do consumers perceive the reliability of online shops?", Cyberpsychology: Journal of Psychosocial Research on Cyberspace, Vol. 3, No. 2, pp. 1.

Hasan, L. \& Abuelrub, E. (2011), "Assessing the quality of web sites", Applied Computing and Informatics, Vol. 9, No. 2011, pp. 11-29.

Hasanov, J. \& Khalid, H. (2012), "The impact of website quality on online purchase intention of organic food in Malaysia: a WebQual model approach", Procedia Computer Science, Vol. 72, No. 2015, pp. 382-389.

Hsieh, M. \& Tsao, W. (2014), "Reducing perceived online shopping risk to enhance loyalty: a website quality perspective", Journal of Risk Research, Vol. 17, No. 2, pp. 241-261.

Hwang, C., Chang, K. \& Chen, M. (2012), "The impact of website quality of customer satisfaction and purchase intention: perceived playfulness and perceived flow as mediators", Information System Electronic Business Management, Vol. 10, No. 2012, pp. 549-570.

Hsu, M., Chang, C., Chu, K. \& Lee, Y. (2014), "Determinants of repurchase intention in online group buying: the perspectives of DeLone and McLean IS success model and trust", Computer in Human Behaviour, Vol. 36, No. 2014, pp. 234-245.

Hu, L., \& Bentler, P. (1995), "Evaluating model fit" In R. H. Hoyle (Ed.), Structural equation modelling: concepts, issues, and applications, pp. 76-99, London: Sage.

Hu, L., \& Bentler, P. M. (1998), "Fit indices in covariance structure modelling: sensitivity to under-parameterized model misspecification", Psychological Methods, Vol. 3, pp. 424453.

Hu, L., \& Bentler, P. M. (1999), "Cut-off criteria for fit indexes in covariance structure analysis: conventional criteria versus new alternatives", Structural Equation Modelling, Vol. 6, pp. $1-55$. 
Huang, Z. \& Benyoucef, M. (2013), "From e-commerce to social commerce: a close look at design features", Electronic Commerce Research and Applications, Vol. 12, No. 4, pp. 246-259.

Hwang, D., Preiser-Houy, L. \& Shang, R.A. (2012), "A comprehensive framework for online store functionalities", Issues in Information Systems, Vol. 13, No. 2, pp. 336-345.

Jackson, T.W. (2007), "Personalisation and CRM", Database Marketing and Customer Strategy Management, Vol. 15, No. 1, pp. 24-36.

Jeon, M. (2009), "Impact of perceived website service quality on customer e-loyalty on a lodging website", Graduate thesis, Iowa State University.

Kabir, M.D.H. \& Carlsson, T. (2010), "Service quality: expectations, perceptions and satisfaction about service quality at Destination Gotland: a case study", Graduate thesis, Gotland University.

Kandari, J. (2010), "Information quality on the World Wide Web: a user perspective", Graduate thesis, University of Nebraska.

Knight, S. \& Burn, J. (2005), "Developing a framewoek for assessing information quality on the World Wide Web", Informing Science Journal, Vol. 8, No. 2005, pp. 159-172.

Kühn, S.W., Spies, H. \& Petzer, D.J. (2015), "Online servicescape as predictors of website trust in the SA domestic airline industry", South African Business Review, Vol. 19, No. 1, pp. 4471.

Levin, A. (2013), "5 types of email online retailers need to master" Available at: http://blog.rejoiner.com/2013/07/types-of-online-retail-emails/\#order_followup (Accessed July 10, 2014).

Liang, T., Lai, H. \& Ku, Y. (2007, "Personalized content recommendations and user satisfactions: theoretical synthesis and empirical findings", Journal of Management Information Systems, Vol. 23, No. 3, pp. 45-70.

Loiacono, E.T., Watson, R.T. \& Goodhue, D.L. (2002), "WEBQUAL: A measure of website quality.", American Marketing Association, Vol. 13, No. 2002, pp. 432:438.

Loke, S., Taiwo, A.A., Salim, H.M. \& Downe, A.G. (2011), "Service quality and customer satisfaction in a telecommunication service provided", International Conference on Financial Management and Economics, IPEDR Vol. 11, pp. 24-29.

Nechkoska, R.P. (2015), "Tactical management in focus: adaptability and information systems", Online Proceeding for Scientific Conferences and Workshops, Vol. 14, No. 15, pp. 1-57.

Prinsloo, D.A. (2016), "Online vs. in-store shopping" Available at: http://www.urbanstudies.co.za/wp-content/uploads/2016/11/SACSC-ResearchReport-Urban-Studies-Online-VS-In-Store-Sho...-2.pdf (Downloaded July 28, 2017).

Ramseook-Munhurrun, P. (2012), "Perceived service quality in restaurant services: evidence from Mauritius", International Journal of Management and Marketing Research, Vol. 5, No. 3, pp. 1-14.

Saha, R. \& Grover, S. (2011), "Quantitative evaluation of website quality dimensions for Web 2.0 environment", International Journal of U- and E-Service, Science and Technology, Vol. 4, No. 4, pp. 15-36.

Sam, M.F.M. \& Tahir, M.N.H. (2009), "Website quality and consumer purchase intention of air ticket", International Journal of Basic and Applied Sciences, Vol. 9, No. 10, pp. 4-9.

Samsi, S.Z.B.M., Jamaluddin, H., Noor, A.Z.M. Mohd, S.N. \& Abdullah, S. (2016), "Information quality, usefulness and information satisfaction in Islamic e-tourism websites", Journal of Theoretical and Applied Information Technology, Vol. 89, No. 2, pp. 450-460.

Schaupp, L.C., Belanger, F. \& Fan, W. (2009), "Examining the success of websites beyond ecommerce: An extension of the IS success model", Journal of Computer Information Systems, Vol. 19, No. 4, pp. 42-52.

Sharma, R.S., Alexander, N., Ho, W.C. \& Arasu, P.K. (2013), "Functional modelling and analysis of IDM e-tailer platforms", International Journal of E-Business Research, Vol. 7, No. 20101, pp. 38-59.

Shin, J.I., Chung, K.H., Oh, J.S. \& Lee, C.W. (2013), "The effects of site quality on repurchase intention in Internet shopping through mediating variables: the case of university 
students in South Korea", International Journal of Information Management, Vol. 33, No. 2013, pp. 453-463.

Swaid, S. I. \& Wigand, R.T. (2009), “Measuring the quality of e-service: scale development and initial validation", Journal of Electronic Commerce Research, Vol. 10, No. 1, pp. 13-28.

Thongpapanl, N. \& Ashraf, A.R. (2011), "Enhancing online performance through website content and personalisation", Journal of Computer Information Systems, Vol. 52, No. 1, pp. 3-13.

Qutaishat, F.T. (2012), “Users' perception towards website quality and its effects on intention to use e-government services in Jordan", International Business Research, Vol. 6, No. 1, pp. 97-105.

Wang, Y.S. (2008), "Assessing e-commerce systems success: A respecification and validation of the DeLone and McLean model of IS success", Information Systems Journal, Vol. 18, No. 5, pp. 529-557.

Webb, H.W. \& Webb, L.A. (2004), "SiteQual: An integrated measure of website quality”, Journal of Enterprise Information Management, Vol. 17, No. 6, pp. 430-440.

$\mathrm{Xu}$, J., Benbasat, I. \& Cenfetelli, R.T. (2013), "Integrating service quality with system and information quality: an empirical test in the e-service context", MIS Quarterly, Vol. 37, No. 3, pp. 777-794.

Yarimoglu, E.M. (2014), "A review on dimensions of service quality models", Journal of Marketing Management, Vol. 2, No. 2, pp. 79-93.

Yu, P. \& Zhao, D. (Eds). (2013), "Effect of website quality factors on success of agricultural products" IFIP International Federation for Information Processing 2014 CCTA 2013, Part II, IFIP AICT 420, pp. 98-113, 2014.

Zeithaml, V.A., Parasuraman, A. \& Molhotra, A. (2002), "Service quality delivery through web sites: a critical review of extant knowledge", Journal of the Academy of Marketing Science, Vol. 30, No. 4, pp. 362-375.

Ziaullah, M., Feng, Y.F., Akhter, S.N. \& Ahmad, S. (2015), “Atmosphere of online retailing quality dimension and development of young generation customers loyalty - an empirical study of China", International Journal of U- and E- Service Science and Technology, Vol. 8, No. 5, pp. 67-82. 